\title{
Third world agricultural centres face a wave of redundancies
}

[NEW DELHI \& LONDON] Growing competitive pressures on internationally funded agricultural research in the developing world has led to severe staff reductions at major research centres in India and the Philippines, with the prospect of layoffs at a third centre in Colombia.

Last week, the International Crops Research Institute for the Semi-Arid Tropics (ICRISAT), near Hyderabad in India, confirmed that 19 of its 81 research staff have been made redundant. And at least another 500 - one-third of the nationally hired staff - are expected to be served notice in the next few weeks.

The move follows an announcement earlier this month that the International Rice Research Institute (IRRI), at Los Baños in the Philippines, was issuing 'separation' notices to 550 individuals - half of its core and mainly local staff. IRRI suffered a deficit of US $\$ 2$ million last year and faces a projected cut of $\$ 6$ million in its budget for 1997 . Somewhat controversially, no non-Filipino has been asked to leave.

It is widely believed that the Centro Internacional de Agricultura Tropical (CIAT), at Cali in Colombia, is next in line for staff cuts.

The three centres are among 16 institutions supported by the 26-year-old Consul- tative Group on International Agricultural Research (CGIAR), a consortium of public and private donor agencies organized through the World Bank. Most of the centres are based in the developing world.

IRRI is the flagship institute of the consortium, with the biggest budget ( $\$ 40.2$ million in 1995). It carries out research on rice production worldwide. ICRISAT, the third-largest institute in the CGIAR system, has been trying to improve crops such as sorghum and millets that grow in arid zones.

James G. Ryan, director general of ICRISAT, said of his institute's staff reductions last week that "we regret [having] to do this but it has become inevitable". He says the institute, whose annual running costs are about $\$ 33$ million, faces a shortfall of $\$ 4$ million in 1997 following a major cut in funding from donor countries. The gap is likely to grow to $\$ 8$ million next year if remedial action is not taken.

The institute has already cut some research programmes in Africa and Latin America. It also introduced a voluntary redundancy scheme in 1994, which helped to cut the workforce by a third, down from a peak of 2,895 in 1991 to 1,737 in 1996.

The centres' troubles can be traced to $1992-93$, when a cut of $\$ 8$ million in US

\section{Icy complexion of Jupiter's frozen moon}

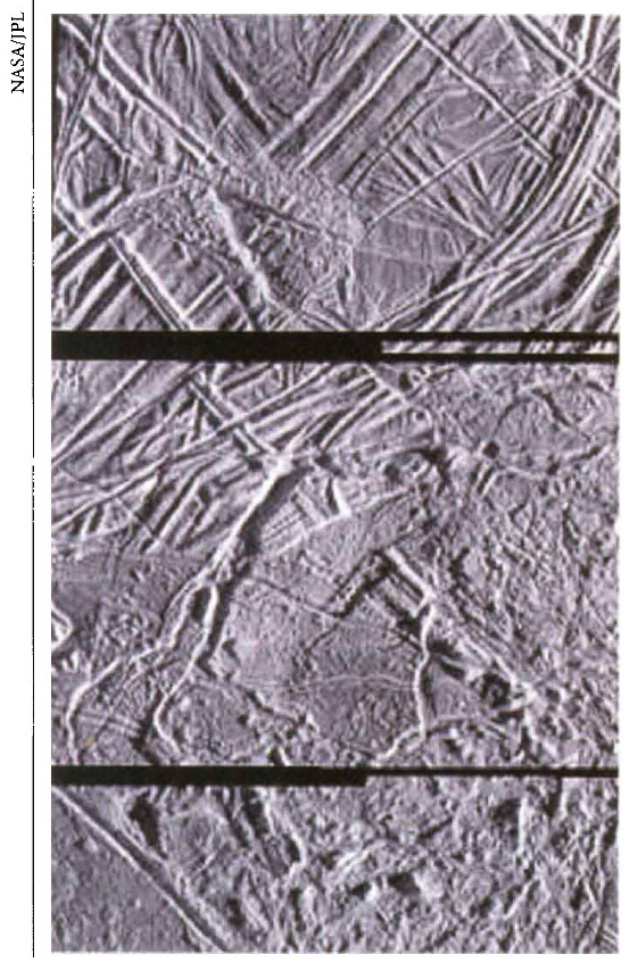

[WASHINGTON] The relative lack of impact craters on the surface of Jupiter's frozen moon Europa indicates that much of the surface is relatively young, according to researchers at the National Aeronautics and Space Administration's Jet Propulsion Laboratory in Pasadena, California, who last week released the first close-up pictures taken by the Galileo spacecraft.

A composite picture of a swathe $11 \mathrm{~km}$ wide, taken last December during the spacecraft's fourth orbit of the planet (left), shows the surface of Europa to be structurally complex, with ice volcanoes and signs of ice flows that probably originated from them, as well as evidence of the movement of tectonic plates.

According to Ronald Greeley of Arizona State University, the images appear to increase the likelihood that Europa is one of the few locations in the Solar System that could have hosted the development of life. But the pictures so far produced by Galileo have not allowed scientists to answer one of the key questions they face - whether a subterranean ocean still exists.

\begin{tabular}{|c|c|c|c|}
\hline \multicolumn{4}{|c|}{$\begin{array}{l}\text { Ranking of contributions to research at } \\
\text { CGIAR centres ( } \$ \text { million) }\end{array}$} \\
\hline Donor & 1991 & 1995 & \\
\hline US & 45.63 & 32.08 & (3) \\
\hline World Bank & 35.11 & 50.02 & (1) \\
\hline Japan & 23.70 & 33.94 & (2) \\
\hline Canada & 15.73 & 12.70 & (7) \\
\hline EC & 13.45 & 16.73 & (4) \\
\hline UK & 11.57 & 9.86 & (10) \\
\hline Germany & 11.04 & 15.84 & (5) \\
\hline Switzerland & 10.16 & 11.94 & (8) \\
\hline UNDP & 6.64 & 8.42 & (11) \\
\hline Netherlands & 6.45 & 12.82 & (6) \\
\hline Denmark & 3.39 (17) & 10.02 & (9) \\
\hline
\end{tabular}

donations triggered a fall totalling $\$ 13$ million in donor support for CGIAR research. As a result, income for the 16 centres dropped from $\$ 247$ million in 1992 to $\$ 234$ million in 1993 .

The World Bank agreed to inject \$20 million in emergency assistance. And an extra $\$ 12.6$ million from other countries helped to restore a degree of balance the following year. But the United States continued to make deep cuts in its annual donation, which had fallen to $\$ 26$ million at the end of 1996 , compared to $\$ 48$ million four years earlier.

By 1994, faced with potential collapse, the management of CGIAR launched an 18month review of its research agenda and funding arrangements. Funding increased to $\$ 302$ million in 1996, largely thanks to the World Bank, Japan and the European Union (see table above).

The 1997 allocation is $\$ 340$ million. But research income is no longer guaranteed, and centres now have to compete for money. They are required to investigate alternative funding sources and to pursue more collaborative ventures with other centres and with national agricultural research councils.

The changes proved controversial. The International Maize and Wheat Improvement Center (CIMMYT) in Mexico, was among the first institutions to be affected. Research income has fallen from $\$ 27.7$ million in 1991 to $\$ 22.3$ million in 1995 . Research staff have been cut from 85 to 65 .

Walter Falcon, chairman of CIMMYT, says funds are "tight". But he says that the worst times have passed, and that the changes - which he describes as "a secondbest solution" - have been painful, and could lead to a reduction in research.

He says many centres are not used to fund-raising, and research time and budgets are being further constrained by the need for collaboration between distant centres. But Falcon points out that the centres could not 


\section{IMAGE UNAVAILABLE FOR COPYRIGHT REASONS}

Testing times: $\mathbf{5 5 0}$ staff at IRRI, the rice research centre, are receiving 'separation' notices.

remain immune from 'donor fatigue' and the introduction of competition in the funding of research, particularly in the developed world. Ryan concurs by saying that a smaller workforce will lead to ICRISAT's research activities being sacrificed and could, if financial problems persist, lead to closure of some of its units in Africa.

But one source close to the agricultural research centre system believes that the cutbacks at IRRI will be less harmful, as they have been designed partly to jolt Asian countries into contributing more to the centre given that " 95 per cent of the world's rice is grown in Asia". He says the cutbacks will not affect research at IRRI as much as anticipated. "IRRI was overstaffed, and a lot of pruning was needed."

Employees at centres hit by the cuts are concerned about the size of the separation pay package. Ryan says that this will be announced after it has been approved by ICRISAT's governing board, which is scheduled to meet at the end of February.

ICRISAT's local Indian staff feel that a confrontation with management over a separation package may be unavoidable because of the institute's refusal to negotiate with its employees about an agreed formula for severance terms.

Local staff, most of whom have 15 to 25 years service, are demanding a minimum of three months' salary for each year of service. Axed Filipino staff at IRRI are to receive between one and two months' salary for each year of service, plus other entitlements.

R.S. Paroda, director general of the Indian Council of Agricultural Research and a member of the ICRISAT board, declined to comment on the sackings as this might be seen as interfering with the institute's autonomy. But he said that his council may employ former ICRISAT staff. Both Paroda and Ryan ruled out speculation that a lack of support could signal the end of ICRISAT's operations in India. "I do not think the fund cuts were directed against ICRISAT," says Ryan, adding that several other CGIAR centres face a similar situation. K.S.Jayaraman\& EhsanMasood
[LONDON] Scientists advising the UK government on radioactive waste disposal have called on the waste management agency Nirex to open up its peer-review arrangements to independent scrutiny if it wants to retain public confidence in its activities.

In a report assessing Nirex's proposals to publish and peer review its science, members of the government's Radioactive Waste Management Advisory Committee (RWMAC) endorse the efforts of Nirex scientists to achieve greater transparency. But they say the peer-review arrangements need revising.

The report appears at a critical time for Nirex. The waste agency is engaged in a heated dispute about the integrity of its public information following the leak of an internal memorandum last week which raises questions about the adequacy of data about the site at Sellafield, in the northwest of England, where Nirex plans to bury waste from nuclear power stations.

Nirex's scientific work is currently assessed by a review panel of external scientists appointed and paid for by the agency. But the RWMAC report, which was published last Tuesday (21 January), says there still remains a perception that the review panel is not fully independent from Nirex. The committee voiced "a residual concern" about the effect this might have on public confidence in the disposal of nuclear waste.

The report suggests that Nirex publish a twice-yearly review report in addition to its proposed biennial document. The report also suggests that learned bodies, such as the Royal Society of Chemistry, should periodically review Nirex's science, and that the agency should submit more of its research to peer-reviewed journals.

Stephen Sparks, a professor of geology at the University of Bristol and former member of Nirex's review panel, says the panel is not afraid to be critical when offering advice. But he acknowledges that the panel's findings are published as "broad suggestions", omitting "the nitty-gritty details".

Sparks says he welcomes the idea of independent assessment of Nirex research. The authority of independent assessors will exceed that of paid consultants, he says, "even if it is the same people". John Holmes, Nirex's director for science, also says he is "content with the report's conclusions".

The memorandum leaked last week, of which Holmes was the author, appears to conflict with the agency's earlier statements. For example, Nirex has repeatedly rejected claims from other scientists and environmentalist groups that more data about the geology and hydrogeology of the Sellafield site are needed before it proceeds with plans to build an experimental underground rock laboratory needed for research into the proposed site (see Nature 383, 751; 1996).

Yet critics say that uncertainty still remains about the movement of radioactive leaks from buried waste through the underground rock, and the possibility that this radioactivity may return to the surface.

In the memorandum, which is dated 10 December 1996, Holmes says he is "concerned" that having spent $\mathfrak{E} 200$ million (US\$320 million), "the modellers are saying that we are short of datapoints by a factor of $10 \mathrm{x}$ or $100 \mathrm{x}$ ". He concludes by suggesting "more site characterization" as one of three options "to get to the bottom of this".

Both statements appear to conflict with evidence given to a public inquiry into the rock laboratory last year at which Holmes said that "it is considered that remaining surface-based activities, while necessary to complete our picture, are very unlikely to substantially change our view of the site".

Holmes says that his more recent memorandum refers to "off-the-cuff comments" made by a modeller and does not acknowledge the need to postpone the rock laboratory and obtain more data instead by drilling additional boreholes. On the contrary, he says, it refers to "the law of diminishing returns" regarding the usefulness of data from boreholes, and that the option of "more site characterization" refers to the need to build the rock laboratory.

Further controversy has been generated by a reference in the memorandum to the contentious issue of the permeability of the site rock to ground water. Holmes writes: "We need to look hard at the [rock] permeability to see if we can justify a lower central [average] value (if not, I have the feeling that we may struggle to make a case for the site)."

Rachel Western, nuclear researcher at Friends of the Earth, argues that this statement suggests that Nirex is "cooking the books". Even Sir John Knill, a former chairman of RWMAC, says that Nirex appears to be "suggesting the goalposts could be moved". According to Knill, the central permeability value is less of an issue, as most groundwater flow will take place at points of high permeability in the rock. He says that 50 per cent of Nirex's permeability values are higher than the central value, and 10 per cent are 100 times higher.

But Holmes says the statement in the memorandum refers to a previous model of rock permeability in which modellers had used an average value of permeability considered by Nirex to be high. 